\title{
MYCL wt Allele
}

National Cancer Institute

\section{Source}

National Cancer Institute. MYCL wt Allele. NCI Thesaurus. Code C53085.

Human MYCL wild-type allele is located in the vicinity of 1 p34.2 and is approximately $7 \mathrm{~kb}$ in length. This allele, which encodes protein L-Myc, is involved in modulation of transcription by RNA polymerase II. 